\title{
変性腰仙椎部後彎に対する後方短縮骨切り術の経験
}

\author{
山口赤十字病院整形外科 \\ 佐々木 邦 雄・大 宮 克 弘 \\ 小川光
}

\section{Posterior Wedge Osteotomy and Shortening for Degenerative Lumbosacral Kyphosis}

\author{
Kunio Sasaki, Katsuhiro Omiya, and Hikaru Ogawa \\ Department of Orthopaedic Surgery, Yamaguchi Red Cross Hospital
}

Degenerative lumbosacral kyphosis occurs due to lower lumbar disc degeneration. Patients with this deformity indicate marked loss of lumbosacral balance. This disalignment disturbs walking and standing ability markedly. Conservative treatment including brace treatment for this deformity is difficult due to the loss of lumbosacral balance.

Surgical treatment had been performed by use of the Isola-Galveston method from only a posterior approach. This procedure was performed to obtain correction and fusion at degenerated discs. Patients operated on by this procedure gained relative relief of symptoms, but loss of correction occurred in the fused area. No correction of the lumbopelvic alignment, measured by the pelvic angle offered by Jackson, seemed to be a major factor of this results.

We changed the operative procedure to gain correction of the pelvic angle and more lumbar lordosis. Posterior transverse wedge osteotomy in the L4 region by the modified eggshell procedure and posterior shortening with spinal instrumentation started from 1997. Three patients were operated on by this method. The Isola-Galveston method was used in one case and the Jackson lumbopelvic fixation method with the Liberty system in another two cases. The fusion area was from L1 to sacrum. After the operation, the pelvic angle was corrected to under 30 degrees and lumbar lordosis over 30 degrees and maintained during follow up. There was no loss of correction and instrumentation failure. Symptoms related to malposture improved markedly in all patients.

Key words : Degenerative Lumbar Spine (変性腰椎), Kyphosis, Osteotomy（後彎, 骨切り術）

\section{緒}

下位腰椎の運動分節の变性ならびに腰背筋の萎縮に

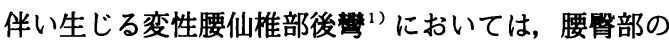
著明なバランス障害の為, 腰痛ならびに両臂部下肢痛 が存在し，立位ならびに歩行障害を生じてくる．歩行 に際しては，歩行車などを必要とし，腰部神経根障害 を合併すると症状はより高度になる．このような症例
に対する手術的治療においての問題点として, 下位腰 椎の椎間板变性に伴う仙椎の後傾及び股関節の前方扁 位, 過伸展位があり, 矯正を必要とする变形である ${ }^{7}$. 我々は以前この変形に対して後方よりの矯正固定を施 行し発表してきたが, 症例における矯正効果が不十分 であり症状の改善ならびに矯正固定位の保持の面で問 題が生じてきだ ${ }^{6 / 9)}$. その後, 手術法に改良を加えた 後方短縮骨きり術 ${ }^{5)}$ を施行し, 腰仙椎部のバランスの 
再獲得が可能であり, 著明な症状の改善をみたので, 手術法ならびに結果について報告する.

\section{手術法}

今回の症例は, 全例 L4 の後方骨切りならびに L34 間での短縮固定を行った. 実際の骨切りのシェーマ を図 1 に示す. 腹臥位にて椎体後方要素を横突起まで 充分に展開する. L4 椎弓は棘宎起も含め切除, L3 の 下関節突起ならびに椎弓, 黄靱帯も部分切除する. L5 の部分椎弓切除も内側関節切除を含め行う. 椎体 側方は椎弓根の外側を前方まで骨膜下に剥離を行う. 展開された術野においてまず横突起を切除, 経椎弓根 的に海綿骨を, 椎体後面を底部とし前方骨皮質を先端 とする楔状に除去する. 前方までの海綿骨の切除後, 後方骨皮質を後縦鞄帯を含め切除する. L3-4 の椎間 板病変の存在する場合は椎間板切除と神経周辺の除圧 操作を行う.これまでの操作にて椎体, 椎間板は後方 を底部とした前方に向かう楔状になる．推弓根内側は 神経根の操作中の損傷をさけるため最後に切除する.

この 1 連の切除術後, 用手的に圧迫力を加え短縮を行 う.この操作にて薄くなっていた側方の骨皮質は骨折 を生じるも，特別の問題はない，短縮部への骨移植は 短縮状態に応じて選択するが， 2 例においては HA,
カーボンケージを使用 1 例は海綿骨のみとした. 後方 短縮後には, 新たに形成された椎間孔に 2 つの神経根 が入ることになる．短縮時に硬膜はたくれ込みを示す が, 短縮距離の調整あるいは L3 の椎弓切除の追加に て, 対処する.

この一連の操作において椎弓切除前に pedicle screwing を行い, 短縮した部位の固定の際仮固定の プレート，ロッドと連結する。

\section{対 象}

1997 年 5 月より 1998 年 5 月の間に 3 例に対して手 術を施行した.

$$
\text { 結果 }
$$

症例の年齢ならびに手術法, 固定範囲, 固定に際し 使用した instrumentation, 手術時間と出血量を表 1 に示す。手術時間は全例 8 時間以上で, 出血量は 2 例 において $2000 \mathrm{ml}$ 以上となったが骨切りのみに伴うの ではなく, 全体の変形矯正を行う必要ああり, このよ うな結果となった。

術前術後のレ線計測値を表 2 に示す. 腰椎前灣は全 例術前 10 度以内であり, 術後 30 度以上が獲得された. また，腰仙椎部バランスを示す骨盤角 ${ }^{4)}$ あ術後良好に

表 13 症例における実施した手術法, 手術時間, 出血量

\begin{tabular}{|c|c|c|c|c|c|}
\hline 症例 & $\begin{array}{c}\text { 手術法 } \\
\text { (骨切り部位) }\end{array}$ & 固定範囲 & 固定法 & 手術時間 & 出血量 \\
\hline $\begin{array}{l}65 \text { 歳 } \\
\text { 女性 }\end{array}$ & L4 頭側 & L2～仙椎 & $\begin{array}{c}\text { Isola-Galveston 法 } \\
\text { PLIF L4-5 (carbon) } \\
\text { L3-4 (HA) }\end{array}$ & $8 \mathrm{hrs} 30$ & $2470 \mathrm{ml}$ \\
\hline $\begin{array}{l}68 \text { 歳 } \\
\text { 女性 }\end{array}$ & L4 頭側 & L2～仙椎 & $\begin{array}{c}\text { Liberty system Jackson 法 } \\
\text { L5-S1 (HA) } \\
\text { L3-4 (carbon) }\end{array}$ & $10 \mathrm{hrs}$ & $790 \mathrm{ml}$ \\
\hline $\begin{array}{l}82 \text { 歳 } \\
\text { 女性 }\end{array}$ & L4 頭側 & L1～仙椎 & $\begin{array}{c}\text { Liberty system Jackson 法 } \\
\text { L4-5 (carbon) }\end{array}$ & $9 \mathrm{hrs}$ & $2,415 \mathrm{ml}$ \\
\hline
\end{tabular}

表 23 症例における術前, 術後のレ線学的計測値

\begin{tabular}{|c|c|c|c|c|c|c|c|c|c|}
\hline & \multicolumn{3}{|c|}{65 歳 F（L1～S1） } & \multicolumn{3}{|c|}{64 歳 F (L2 S1) } & \multicolumn{3}{|c|}{82 歳 $F(L 1 \sim S)$} \\
\hline & 術前 & 術後 & 最終 & 術前 & 術後 & 最終 & 術前 & 術後 & 最終 \\
\hline 固定椎間角 & 10 & 33 & 35 & -3 & 35 & 32 & -10 & 33 & 31 \\
\hline 腰椎前笉 & 6 & 31 & 26 & 9 & 43 & 38 & -10 & 33 & 31 \\
\hline 仙 椎 傾 斜 & 6 & 26 & 23 & 18 & 38 & 30 & 20 & 31 & 32 \\
\hline 骨 盤 角 & 54 & 34 & 32 & 22 & 7 & 13 & 42 & 26 & 21 \\
\hline
\end{tabular}





図 1 後方揳状骨切り術と後方短縮術のシェーマ

後方骨切り

椎弓根経由にて海綿骨ならびに骨皮質を楔状 に切除

合併せる椎間板病变にも処置

なり 30 度以内であった.この良好な腰仙椎部バラン スの獲得により, 固定椎間角の喪失むなく骨癒合した.

\section{症 例 呈 示}

症例 $1 ; 68$ 歳女性

主 訴; 腰痛, 両下肢痛, 歩行障害

既往歴 ; 慢性関節リュウマチ（17 年前発症, 7 年 前よりステロイド使用, ステロイド誘発の糖尿病の合 併あり）

平成 8 年 8 月より腰痛が出現. 平成 9 年 7 月より両 下肢痛が出現, 8 月より疼痛のため自宅内生活を余儀 なくされ, 毎日疼痛に対して坐薬を使用, 移動は車椅 子にて行うようになった.

現 症; 立位, 独歩不能. 神経学的に異常所見なし. 検査結果 ; 腰仙椎部のアライメントは維持されてい るむ L3 の前方すべりと同部での後彎形成が著明であっ た.

手術法; 本症例は背筋の萎縮も著明であり, 腰仙椎 部の固定法として, Liberty system 使用での Jackson 法 $^{3)}$ を行い, 骨切り後 L3-4 間にはカーボンヶー ジ使用での椎体間固定を行った. 術後アライメントの 改善もよく, 一時的に右 L4 神経根の障害を示すも改
後方短縮

骨切り部ならびに椎間板部にたいしては変形 の程度に応じた椎体間固定を施行

後方インステゥルメンテーションにて短縮
善, 術前の症状は消失した（図 2 ).

症例 $2 ; 82$ 歳女性.

主 訴; 腰痛, 両整部痛, 両大腿前面痛, 歩行障害 既往例；特記すべきことなし

生活歷 ; 50 歳まで農業, 林業の重労働に従事. 50〜65 歳まで食堂にて働く.

現病歴 ; 60 歳ごろより腰痛が出現, 70 歳ごろより 腰痛のため歩行距離が短くなった．また，このころよ り両大腿前面痛も出現, 各種治療を受けるも改善なし. 下肢痛ならびに腰痛は $50 \mathrm{~m}$ 以内の歩行にて出現する ようになる。

入院時現症; 腰椎は後側鸺を呈し体幹は前傾してい た. 傍脊柱筋は著明に萎縮し伸展は不能. 腰部は中下 位に圧痛あり．神経学的に両大腿神経過伸展試験陽性， ラセーグ徴候はなし. 知覚, 筋力に異常なし. 両下肢 の股関節，膝関節に異常所見なし.

手術法; 本例においても, 固定法として Liberty system 使用での Jackson 法 ${ }^{3)}$ を用いた。 L4 にて骨 きりを施行, L3-4 の椎間板変性むあきらかであり椎 間板ならびに骨棘を充分切除. 後方の短縮を行うと, L3-4 の椎間板高の減少は明らかであり, 海綿骨を充 填し椎体間固定をおこなった（図 $3 \mathrm{~A}$ ). 

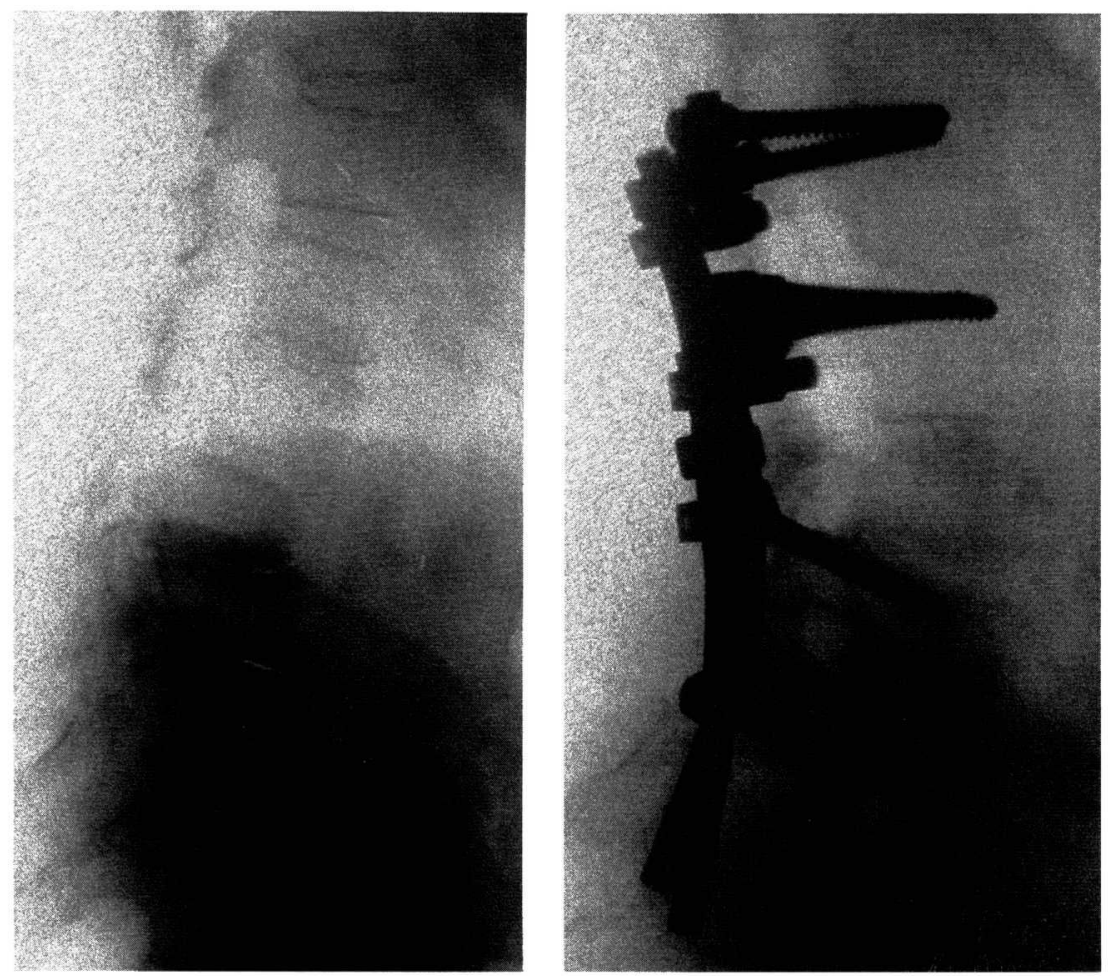

図 264 歳, 女性.

術前, L4-5, L5-S1 の著明な椎間板狭小化と L3 すべりが存在し腰椎前省は 9 度と減少していた. 術後, 前彎は 43 度, 仙椎傾斜 38 度, 骨盤角は 7 度となり, 良好なアライメントが獲得された.

術後経過; 術後 L4 の刺激症状が出現するも改善, $\mathrm{T}$ 杖にて歩行も可能となった。手術前の後側彎に伴う 前傾姿勢も改善, 良好な腰椎前彎が獲得された（図 3 B).

\section{考察}

高秢者における胸腰椎〜腰仙椎部の变形において臨 床的な問題となるものは, 骨盤後傾を伴う変形であり, 保存的治療は困難である. 腰仙椎部アライメントの残 存せる後彎姿勢においては, 装具治療は可能であるも,

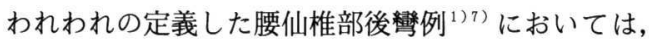
骨盤の固定が装具では不能であり, 通常の生活は困難 を生じる姿勢である.このような变形例においては, 日常生活之くに歩行においては, バランスを維持する ためのいわゆる老人車が有用である. しかし，手術的 治療を希望される症例においては, 矯正固定が考虑さ れる，以前我々は Isola-Galveston 法を用いての矯
正固定の有効性を報告した ${ }^{8)}$. しかし, 症例の追跡調 查において，腰椎前彎の獲得は充分でなく，また固定 椎間の矯正製失が生じていた。この要因を股関節を含

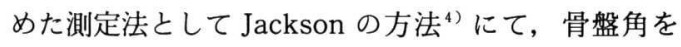
測定すると, 腰椎の椎間板操作のみによる後彎の矯正 では骨盤角の矯正は獲得されず，経過中矯正喪失を生 じる主な原因と考えられた ${ }^{6) 9}$. 即ち, 骨盤角を 30 度 以内になるような矯正固定を行わないと, 重心線より の下位腰椎への距離は大きいままであり,この部に対 する伸張力は後方より椎体間固定を行っても大きいも のであり, 徐々に矯正喪失をむたらしたと考えられた. 椎間板変性によりもたらされた骨盤後傾を伴う後彎 変形に対する手術的治療法として, 前方を開大, 前方 固定する必要性が竹光 ${ }^{10)}$ により提唱されているが, こ のような変形存在例にたいする下位腰椎部への前方進 入は大血管に対する処置を考えると躊踷され我々は後 方よりの矯正を考えた. 後方よりの矯正においては, 



図 3 A 82 歳, 女性.

術前, 椎体間のすべりを伴う側彎と著明な前傾姿勢あり．骨盤角は 54 度であった． 術後，腰椎 アライメントの改善は著明であり, 腰椎前彎 31 度, 仙椎傾斜 26 度, 骨盤角 34 度となった。

以前使用した椎間板操作のみでは矯正不足であり, 短 縮による前樂獲得が効果的と考えた，後方短縮におい ては, 強直性脊椎炎の届曲変形に Smith-Petersen が 考案した梀突起と椎弓切除のみ行う骨切りによる矯正 は不十分であり，椎体も含め後方を切除し前縦勒帯を hinge とする短縮法を採用した，後方よりの骨切除法 は Heinig ${ }^{2)}$ の考案した eggshell procedure を基本と して採用した.

今回 3 例に対し前彎獲得，腰椎一股関節バランスの 良好な再獲得の為，L4 に打いて短縮骨切りを行い良 好なアライメントが得られた，変性後彎に打ける固定 範囲として我々の選択した上位腰椎部は生理的な胸椎 後彎と腰椎前彎の移行部であり, 脊柱全体のバランス よりみると屈曲力に弱く今後隣接部における後彎発生 が危惧されるが，固定範囲に関しては，症例每のアラ イメント評価法も含め今後の問題となる.

結

語

変性性腰仙椎部後彎例に対する 1 手術法としての, 後方楔状型骨きり短縮法を紹介し, 手術例 3 例の詳細
を報告した。

\section{参 考 文 献}

1）石谷栄一他：変性性腰仙惟部後彎の X線学的分類及び 治療. 日本春椎外科学会誌，5：332，1994.

2) Heinig CF. Eggshell procedure. In Luque E, ed. Segmental Spinal Instrumentation. New Jersy : Slack, 221-234, 1984.

3) Jackson RP. : Jackson sacral fixation and contoured spinal correction techniques. In Margulies JY, ed Lumbosacral and Spinopelvic Fixation. Lippincottraven, Philadelphia. 357-379, 1996.

4) Jackson RP. : Spinal balance, lumbopelvic alignment around the hip axis, and positioning for surgery. State of Art Reviews (Spine), 11: 33-58, 1997.

5) Lehmer SM et al. : Posterior transvertebral osteotomy for adult thoracolumbar kyphosis. Spine 19 : 2060-2067, 1994.

6）松本嘉寛他：変性腰椎多椎間固定例における矢状面 alignment の変化. Isola system 使用例における. 整, 災外, $41: 1393-1398,1998$.

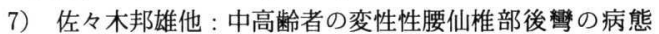
と治療. 整外之災外，43:1362-1365, 1994.

8）佐々木邦雄他 : 变性性腰仙椎部後彎に対する手術的治 

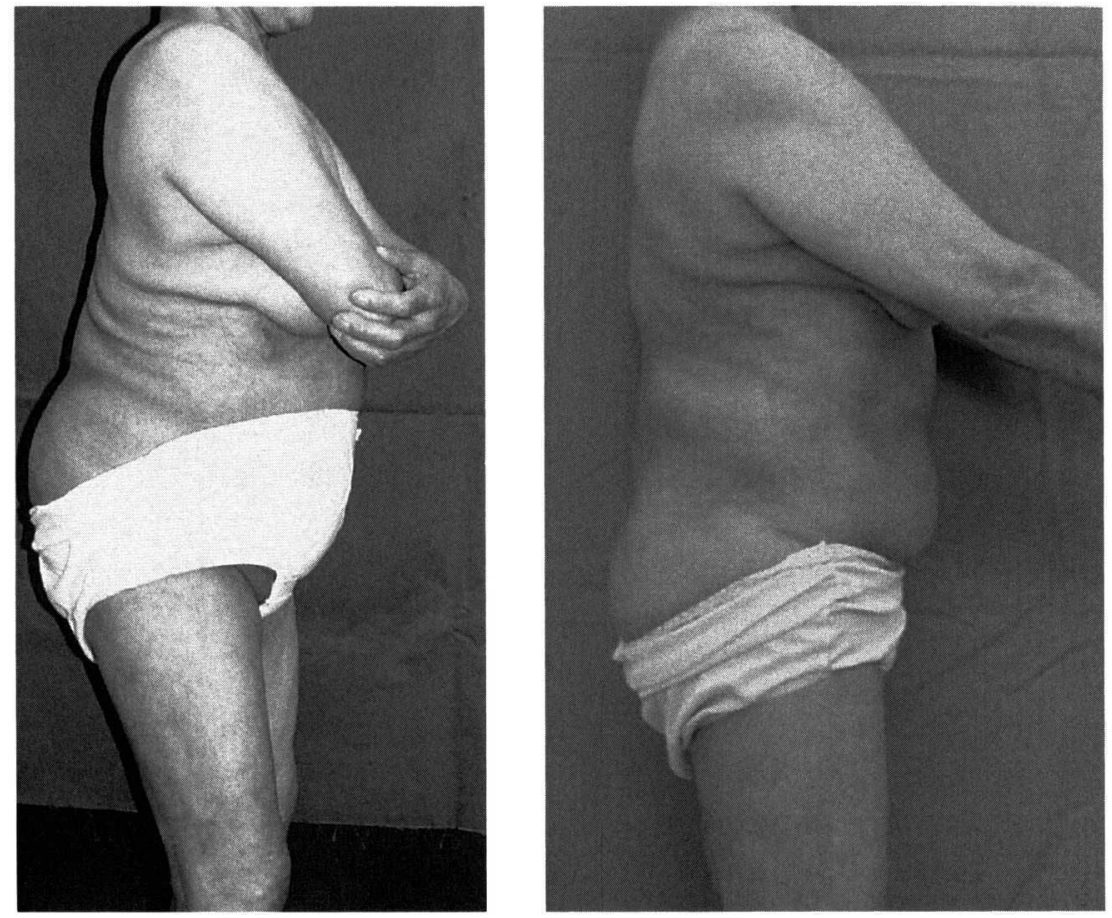

図 3 B 82 歳, 女性.

術前著明な前傾姿勢であり，腰椎前彎は消失していた，術後，腰椎前彎も獲得され姿勢バランス あ良好となった。

療. 脊柱変形 $10: 153-155,1995$.

9）佐々木邦雄他：变性性腰椎変形に対する instruentation surgery. 多椎間病変存在例に対する。 中部整災
誌, $40 ： 1233-1234 ， 1997$.

10）竹光義治他 : 高齢者の各種後彎之腰痛. 整，災外， 36 : 901-907, 1993. 